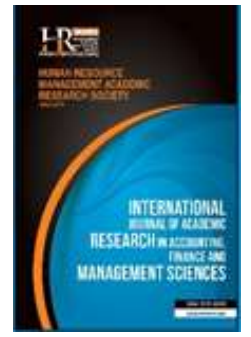

International Journal of Academic Research in Accounting, Finance and Management Sciences

Vol. 10, No.2, April 2020, pp. 15-30

E-ISSN: 2225-8329, P-ISSN: 2308-0337

(c) 2020 HRMARS

www.hrmars.com

To cite this article: Agbo, E.I., Nwadialor, E.O. (2020). The Genesis and Development of Value Added Tax Administration: Case Study of Nigeria, International Journal of Academic Research in Accounting, Finance and Management Sciences 10 (2):15-30

\title{
The Genesis and Development of Value Added Tax Administration: Case Study of Nigeria
}

\author{
Elias Igwebuike Agbo ${ }^{1}$, E.O. Nwadialor ${ }^{2}$ \\ 1,2Department of Accounting and Finance, Faculty of Management and Social Sciences, Godfrey Okoye University, \\ Ugwuomu-Nike, Emene, Enugu State, Nigeria \\ ${ }^{1}$ E-mail : agboelias@ymail.com (Corresponding author)
}

\begin{abstract}
This paper has the cardinal objective of carrying out a survey on the genesis and development of value added tax (VAT) administration. Specifically, the study intends to examine the origin and popularity of the VAT system globally, identify its emerging issues and the related consequences. Also, it is directed at ex-raying the development of VAT and its computational analysis, particularly as it relates to Nigeria. Empirical studies indicate that VAT has gained much popularity universally, inspite of its several emerging issues. That notwithstanding, it is speculated that, in the near future, VAT is likely to be replaced with retail sales taxes both in substance and in reality; it will be managed and administered almost entirely through the use of technology and be expanded in several ways. In Nigeria, the VAT law has gone through several amendments. The latest of the amendments which led to an increase in its rate by fifty per cent generated fierce debates among several interest groups. This study finds that the recent VAT increment may end up enhancing the total revenue of Nigeria but may have some negative effect on the per capita income of the polity. This likely consequence can be averted only if necessary palliative measures are taken concurrently. The study therefore advises the Nigerian government to have a second look at the necessity and timing of the current Value Added Tax increase and take the appropriate remedial actions.

Key words

Value Added Tax Administration, Nigeria, Global VAT Issues

\begin{tabular}{|c|c|c|}
\hline Received: & 13 Apr 2020 & (C) The Authors 2020 \\
\hline Revised: & 10 May 2020 & Published by Human Resource Management Academic Research Society (www.hrmars.com) \\
\hline $\begin{array}{l}\text { Accepted: } \\
\text { Published Online: }\end{array}$ & $\begin{array}{l}15 \text { May } 2020 \\
04 \text { Jun } 2020\end{array}$ & $\begin{array}{l}\text { This article is published under the Creative Commons Attribution (CC BY } 4.0 \text { ) license. Anyone may } \\
\text { reproduce, distribute, translate and create derivative works of this article (for both commercial and } \\
\text { non-commercial purposes), subject to full attribution to the original publication and authors. The full } \\
\text { terms of this license may be seen at: } \underline{\text { ttp://creativecommons.org/licences/by/4.0/legalcode }}\end{array}$ \\
\hline
\end{tabular}
\end{abstract}

\section{Introduction}

The Value Added Tax that was not promising future success when it began in the early 20th century has been adopted by more than 160 countries at the moment and is reported to be accounting for approximately 20 percent of the total global tax revenue (James, 2011; Gerard \& Naritomi, 2020). According to James(2011), it is only the income tax that can provide a stronger example of the 20thcentury tax policy convergence. In the recent times, vitually all the countries in the universe (both developed and developing) are struggling to,at least, reduce their escalating budget deficits.Expectedly, many of them have adopted one form of VAT or the other because they consider VAT as a veritable means for boosting their itnternally generated revenue.

In many economies, the ability to generate sustainable revenue has remained a huge challenge (Ezomike \& Ango, 2019).For those nations that produce and export petroleum, this urgly situation is amplified by the incessant decline and instability in crude oil prices (Thornton, 2017). 
In spite of the gains that made from the introduction of national broad-based Value Added Tax globally, its adoption by some developed countries such as United States, Australia, Canada and Japan has been rather sluggish (James, 2011). The VAT critics in such jurisdictions have argued that VAT is essentially a regressive tax which, apart from adding bureauratic burdens on businesses, places an increased economic strain on the lower-income taxpayers (Kagan, 2020). Further, there is ample evidence that the governments of many developing countries that have adopted VAT harvest huge revenue yields therefrom. Ironically, they continue to complain of insufficient fund to carry out their statutory obligations to their citizens. The latter often complain of poor infrastructural facilities, unemployment, low per capita income, poor living standards sophisticated crimes and other social ills (Ugochukwu \& Azubike, 2016). This has motivated a lot of inquiries on the true relationship between VAT and a developing country's Gross Domestic Product (GDP).

\section{An Overview of Value Added Taxation}

For several decades, the Value Added Tax revenue has accounted for a significant percentage of the total public revenue universally (Ugochukwu \& Azubike, 2016). Jenkins \& Kuo (1995) assert that VAT has been adopted by several nations as a result of the growing concern about economic efficiency and tax simplicity in the competitive and integrated world economy. The significant contribution of VAT to total government revenue in countries where it has been in existence is noticeable. This has continued to influence governments' decision to introduce VAT as an alternative to the sales tax regime.

\subsection{Origin of VAT}

According to James (2011), there is yet to be a concensus on the exact origin of VAT. While some scholars trace VAT's genesis to a German entreprenuer, Wilhelm Von Siemens, who carried out his study in 1918 , others attribute its origin to an American economist, Thomas S. Adams whose literary work spanned from 1910 to 1921 (Adams, 1921; Sulivan, 1965). Von Siemens's concept of VAT was considered as a new technical method that simply modified the turnover tax. The VAT promoted by the author allowed for the recovery of the taxes paid on business inputs and avoided the several problems that arise with a turnover tax.On the other hand, Adams introduced VAT as an alternative to the business income tax.

The fate of VAT in Western Europe and the United States(U.S.) largely reflects the different motives of the two VAT innovators. While Germany and much of Western Europe consider VAT as a superior technical modification to sales taxes, and as an adjunct to the income tax, the U.S. policymakers consider it as a substitute for the Federal income tax; the U.S. policymakers regard the envisaged replacement of income tax with VAT as unnecessary (Jayachandran, 2019).

\subsection{The Rise of VAT}

France was the first country to administer VAT at a national level. This commenced in April, 1954 (James, 2011). In the beginning, its coverage was limited and it was in 1968 that France proceed to a full VAT that reached the broader retail sector. In Denmark, the first full VAT was enacted in 1967.

The adoption of VAT progressed in two major phases. While the first phase took place mostly in the Western Europe and Latin America during the 1960s and 1970s, the second phase of VAT adoption occurred in the late 1980s. Thereafter, VAT got to be adopted in some industrialized countries outside the European Union, namely Australia, Canada, Japan, and Switzerland. The second phase also witnessed the rapid expansion of VAT in both transitional and developing economies, especially in Africa and Asia. This was facilitated by the key influences of the International Monetary Fund and the World Bank.

\subsection{VAT's Popularity}

Abdullah, Duocoulagos \& Manning (2015) report that VAT stands out as one of the most important tax policy innovations, after the introduction of the personal income and witholding taxes. VAT has spread to a great majority of countries. At the moment, almost all the advanced and emerging nations have adopted. The Pwc (2020) report on Worldwide Tax Summaries highlights the countries that have adopted VAT. The nations and their respective VAT rates are as follows:-Albania $20 \%$; Algeria 19\%; Angola $14 \%$; 
Argentina 21\%; Armenia 20\%; Australia Goods and services tax 10\%; Austria 20\%; Azerbaijan 18\%; Bahrain 5\%; Barbados 17.5\%; Belarus 20\%; Belgium 21\%; Bolivia13\%; Bosnia and Herzegovina 1\%; Botswana 12\%; Brazil Federal VAT (IPI): normally around $10 \%$ to $15 \%$; State sales and service tax (ICMS): normally around $18 \%$ to 20\% (lower rates apply to inter-state transactions). Bulgaria 20\%; CapeVerde 15\%; Cambodia Taxable supply in Cambodia: 10\%; Taxable supply for export: Cameroon, Republic of $19.25 \%$; Canada Combined federal and provincial/territorial sales taxes range from $5 \%$ to $15 \%$. Chad $18 \%$; Chile $19 \%$; China People's Republic of $13 \%, 9 \%$, or $6 \%$ depending on the types of goods and services; Colombia $19 \%$; Congo, Democratic Republic of the16\%; Congo, Republic of $18.90 \%$; (18\% VAT + 5\% surtax) Costa Rica 13\%; Croatia 25\%; Cyprus 19\%;Czech Republic21\%; Denmark25\%; Dominican Republic18\%; Ecuador 12\%; Egypt 14\%; El Salvador13\%; Equatorial Guinea 15\%; Estonia 20\%; Fiji 9\%; Finland 24\%; France Turnover tax: 20\%; Gabon 18\%; Georgia 18\%; Germany 19\%; Ghana 12.5\%; Greece 24\%; Greenland NA; Guatemala 12\%; Guernsey, Channel Islands NA; Guyana 14\%; Honduras Sales tax: 15\%; Hong Kong NA; Hungary 27\%; Iceland 24\%; India Goods and services tax: 18\%; Indonesia 10\%; Iraq Sales tax: Varies by good/service (see Iraq's corporate tax summary). Ireland 23\%; Isle of Man 20\%; Israel 17\%; Italy 22\%; Ivory Coast (Côte d'Ivoire) 18\%; Jamaica General consumption tax: 16.5\%; Japan Consumption tax: $8 \%$; Jersey, Channel Islands Goods and Services Tax (GST): 5\%; Jordan Sales tax: 16\%; Kazakhstan 12\%; Kenya 16\%; Korea, Republic of10\%; Kosovo 18\%; Kuwait NA; Kyrgyzstan 12\%; Lao PDR 10\%; Latvia 21\%; Lebanon 11\%; Libya NA; Liechtenstein 7.7\%; Lithuania 21\%; Luxembourg 17\%; Macau NA; Macedonia 18\%; Madagascar 20\%; Malawi 16.5\%; Malaysia Sales tax: 10\%; Service tax: 6\%; Malta 18\%; Mauritius 15\%; Mexico 16\%; Moldova 20\%; Mongolia 10\%; Montenegro 21\%; Morocco 20\%; Mozambique 17\%; Myanmar There is no VAT in Myanmar. The indirect tax in Myanmar is commercial tax, with the general rate of $5 \%$. Namibia, Republic of $15 \%$; Netherlands 21\%; New Zealand Goods and services tax (GST): 15\%; Nicaragua 15\%; Nigeria 5\%; increased to 7.5\% effective 1 February 2020; Norway 25\%; Oman NA; Pakistan 17\%; Palestinian territories 16\%; Panama Movable goods and services transfer tax: 7\%; Papua New Guinea Goods and services tax: 10\%; Paraguay 10\%; Peru 18\%; Philippines 12\%; Poland 23\%; Portugal 2.3\%; Puerto Rico Sales and use tax: $11.5 \%$ for tangible personal property and certain services; $4 \%$ for business-to-business services and designated services.; Romania 19\%; Russian Federation 20\%; Rwanda 18\%; Saint Lucia 12.5\%; Saudi Arabia 5\%; Senegal 18\%; Serbia 20\%; Singapore Goods and services tax: 7\%; Slovak Republic 20\%; Slovenia 22\%; South Africa 15\%; Spain 21\%; Sri Lanka 15\%; Swaziland 15\%; Sweden 25\%; Switzerland 7.7\%; Taiwan 5\% to general industries; Tajikistan 18\%; Tanzania 18\%; Thailand 7\%; Timor-Leste Sales tax on imported goods: 2.5\%; Sales tax on other goods: 0\%; Trinidad and Tobago 12.5\%; Tunisia 19\%; Turkey 18\%; Turkmenistan 15\%; Turks and Caicos Islands NA; Uganda 18\%; Ukraine 20\%; United Arab Emirates 5\%; United Kingdom 20\%; United States NA; Uruguay 22\% (reduced 10\% VAT rate applicable to certain goods and services). Uzbekistan, Republic of 15\%; Venezuela 16\%; Vietnam 10\%; Zambia 16\%; Zimbabwe 15\%; (to be reduced to $14.5 \%$ effective 1 January 2020).

In June 2016, the six GCC countries (Bahrain, Kuwait, Oman, Qatar, Saudi Arabia (KSA) and the United Arab Emirates (UAE) signed the GCC VAT Framework Agreement. The Framework Agreement contains a common set of VAT rules on the basis of which the separate GCC countries agreed to introduce their own VAT regimes within. Under the Framework Agreement, the GCC countries agreed to introduce VAT at a standard rate of $5 \%$ and apply it to most supplies of goods and services that are (considered to be) supplied within the respective jurisdiction; the import of goods and services are inclusive.

According to Obadan (2015), many countries have standard VAT rates in the range of 10-25 percent. Obadan further reveals that only few countries such as Nigeria, India and Malaysia have low VAT rates. On the other hand, some countries such as; USA, Libya and Hong Kong are VAT-free. Literature reveals that up to eighty percent of the countries in the sub-Sahara Africa have already adopted the VAT. The tax is now responsible for generating about one-quarter of all their tax revenues.

\subsection{The Revenue Generating Potential of VAT}

As is usual with every other tax, the revenue-generating potential of VAT in a country is relative to the country's administrative capacity. VAT generates far less revenue, and does so far less efficiently, in countries with weak administrative capacity (Skogstad \& Galagher, 2010; Salia \& Atuilik, 2016). Even when supported by high-level administrative capacity, the real-world VATs are not perfectly exemptable from tax 
avoidance and evasion activities. Most of the VAT challenges involve taxpayers' exploitation of the credit invoice mechanism. For instance, according to Norregaard \& Khan (2007), the annual cost of VAT fraud within the European Union (EU) alone was estimated at $\$ 340$ billion.

The workability of VAT system in developing countries has been hotly debated. Within the theoretical work on the subject, Emran and Stiglitz (2005) cited in Alavuotunki,Haapanen and Pirtilla (2019) have argued that VAT can be problematic when an economy has a large informal sector.The implication is that, since most developing countries have large informal sectors, VAT is not appropriate for them. In the contrary, Keen (2008) contends that, though indirectly, the informal sector also pays VAT since it is levied on some of the inputs which the sector uses.

\section{Literature review}

\subsection{Conceptual Framework}

\subsubsection{The Concept of Value Added Tax}

The concept of Value Added Tax as a concept originated from the French Economist, Maurice Laure. It was originally referred to as "taxe sur la valueur". Omesi \& Nzor (2015) define VAT as a consumption tax payable on the goods and services consumed by persons, business organizations and individuals (Fowler, 2016; Embuka, 2012; Kagan, 2020).The VATs payable by tax payers depend on their consumptions rather than their incomes.VAT applies equally to every purchase. In contrast with a progressive income tax, it does not discriminate among the classes of income earners. In some countries, VAT is called Goods and Services Tax (GST). According to Ezejulue (2001), VAT has some merits over other types of taxes when judged from the point of view of tax neutrality, revenue earning capacity, efficiency, and broadness of base.

\subsubsection{Varieties of VAT}

There are three major varieties of VAT, namely the European model, the New Zealand model and the Japanese model. Among the three types, the New Zealand model is considered to be closest to resembling an ideal VAT. According to James (2011), most jurisdictions have adopted a European-style VAT which is marked by multiple rates and varying degrees of exemptions. In practice, no two VAT systems are perfectll similar; they differ in rates, thresholds, exemptions, refund, and coverage. While some VATs systems exist sub-nationally or are limited to the manufacturing or wholesale level,others exist nationally.

\subsubsection{Features of a Good Value Added Tax system.}

According to Messre \& Norregard (1999) cited in Ugochukwu \& Azubike (2016), a VAT system is ideal to the extent that

(i) its interference with the choices made by both producers and consumers is minimal;

(ii) it is accompanied by appropriate change in other taxes and in the social transfer system to alleviate or neutralize its negative distributional consequences;

(iii) it does not lead to sustained inflationary pressures either at its introduction or in the long run;

(iv) it generates huge amounts of revenue for the government and minimises the possibility of tax evasion and avoidance and

(v) it minimizes government's administrative and compliance cost.

James (2011) observes that commentators generally agree on what constitutes an ideal or 'good' VAT regime. The prescriptions according to James entail a flat rate VAT that extends through to the retail stage of the economy and a VAT that is levied on a broad consumption base of goods and services with minimal exclusions.

\subsection{Theoretical Framework}

Some of the important theories of taxation include the social political theory, the expediency theory, the benefit- received theory, the cost of service theory and the ability-to-pay theory.This study is anchored on the benefit- received theory and the cost-of-service theory which are stated briefly below. 


\subsubsection{Benefit-received theory}

As a result of the inefficiency of the private market, the provision of public goods like security of life and property which the public is not prepared to pay for directly, are provided by the government instead of the private market (Miller \& Oats, 2009). The Benefit-received theory is built upon the claim that tax payment should open up an exchange relationship between the tax payers and the government.The explanation for this is that while the government provides certain goods and services to its citizens, the latter should bear the cost of these supplies to match with the benefit received (Bhartia, 2009; Anyafo, 1996).

\subsubsection{Cost-of-service theory}

The proponents of this theory maintain that some semi-commercial relationship exists between the State and tax payers. They argue that as the State performs some basic protective and welfare functions their citizens have to make some contributions in the form of taxes so as to cover the cost of those services.

\subsection{Empirical review}

Taxation is necessitated by the fact that governments all over the universe have to generate sufficient revenue to be able to carry out their statutory responsibilities (Abiola \& Asiweh, 2012). Some of the literature related to the importance and relevance of VAT in revenue generation and national economic growth have been reviewed as summerized below.

Ajakaiye (1999) studied the macroeconomic effects of VAT in Nigeria using a computable general equilibrium analysis. The result of the study showed evidence that VAT is a significant source of revenue in Nigeria.

In a related but broader study, Remer \& Romer (2000) found that VAT can increase economic growth. However, VAT can do so only when enforcement and implementation procedures are efficient. This observation was re-echoed in the results of the study of McCarten (2005). Going forward, Ajala et al., (2010) invesigated the impact of VAT on revenue generation in Nigeria. The results of the study show that VAT has a statistically significant effect on revenue generation in Nigeria.

In a similar study where Keen \& Lockwood (2010) wanted to determine the efficacy of VAT in enhancing revenue generation, they discovered that VAT is a 'money machine' and has helped countries to generate more revenues than they would have done if it were not in place. Still going forward in the similar investigations, Unlukaplan, (2010) focused on ascertaining the effect of direct-indirect tax on economic growth of Kurkish within the period of 1968-2006. The result of their study shows that real output is positively related to indirect tax revenue while direct tax has no significant effect.

Ebiringa \& Emeh (2012) equally examined the impact of the forms of tax on the economic growth in Nigeria, using secondary data coering the period between 1985 and 2011. The result of the study shows that only custom and exercise duties are capable of influencing the gross domestic product (GDP).However, custom and excise duties were found to be having a negative and significant relationship with the GDP. Aniechebe (2013) examined the impact of tax on economic growth in Nigeria between 1986 and 2011. Employing some econometric model, the author found a significant corelation between tax composition and economic growth. Going further inthe analysis, it was observed that there is a significant positive connection between direct, indirect tax and economic growth but that the relationship between total tax revenue and economic growth is negative. That same year, Bakare \& Adewale (2013) to find out the enormity of the impact of VAT on output growth in Nigeria using the Ordinary least square regression analytical technique (OLS). They found that a positive and significant relationship exist between VAT and output growth in Nigeria.

Taking on from the previous works, Yakubu \& Jibrin (2013) studied the impact of VAT on economic growth of Nigeria using Johansen Co integration test. The result shows that VAT has a positive impact on economic growth of Nigeria.

The outcome of a similar study carried out by Bakare et al. (2013) to determine the enormity of the impact of VAT on output growth in Nigeria discloses a positive and significant relationship between VAT and output growth in Nigeria. 
Am ong the studies reviewed by this paper, other studies that observed positive impact of VAT on economic growth of Nigeria include Onodugo and Anowor (2013), Okoyeuzu (2013), Okwori \& Ochinyabo (2014), Efurueze \& Ekezie (2014), Afplayan \& Okoli (2015), Obiakor et al. (2015) and Olaniyi et al. (2019).

Contrary to the results of those works, a number of more recent works emerged with results that suggest that either the effect of VAT on the economic growth is negative or that VAT has no effect on Nigeria's GDP. For instance, after examining the dynamic causal relationship between tax revenue components and economic growth in Nigeria using time series data on different types of Taxes and Real GDP for the period from 1986 to 2012, John et al. (2014) found that. That even though total tax revenue has a significant effect on economic growth, no significant causal relationships exists between VAT and economic growth.

Similarly, Loveday \& Nwanyanwu (2015) studied the VAT administration in Nigeria and examined the relationship between irrecoverable invoices and VAT compliance. Twenty small and medium enterprises (SMEs) in the leasing, manufacturing and construction subsectors of the economy were emloyed as samples. The results indicate that there is a statistically significant and negative relationship between irrecoverable invoices and VAT compliance. Others studies that reported negative effects of VAT on Nigerian economic growth include Ugochukwu \& Azubike (2016) as well as Oraka et al. (2017).

From a broader perspective, Alavuotunki et al. (2018) strived to ascertain the impact of VAT and autonomous revenue authorities on the tax revenues of 47 Sub-Sahara African countries over the period from 1980 to 2010. The results of the study show that VAT has no effect on total revenues both in the short run and long run.

\section{Emerging Global VAT Issues, Consequences and Recommended Approaches}

Several issues are emerging globally concerning the VAT regimes. One of such critical issues is the challenge emanating from the difficulty in subjecting internationally traded services or intangibles to border controls and the customs procedure in the same manner as can be done for goods. One consequence of this issue is that, tax authorities have taken uncoordinated and unilateral actions in response. Reactions like this have, in turn, tended to make policy risks to become increasingly complex. Another fall out from the uncoordinated reactions of tax authorities is the continued increase of the risks of non-taxation, double taxation, revenue risks and high compliance costs. To salvage the situation, several collective efforts have been made by international organizations to identify the issues and adopt practical approaches to address them. For instance, the work of the Organization of Economic Community for Development (OECD) on VAT in recent years has focused primarily on the development of internationally accepted standards and recommended approaches for the consistent, efficient and effective application of national VAT/GST systems.

Some additional emerging issues of VAT have been highlighted in Carter (2013), namely the issues relating to establishing the appropriate number of VAT rates, the exemptions to be granted, the appropriate level of threshold and the suitability of introducing VAT in small countries. Others have to do with international issues, federalism, how best to organize the VAT administration, self-assessment procedures, VAT audit and VAT refunds. Other global emerging issues highlighted in literature include the difficulties in taxing hard-to-tax sectors like farming, the treatment of financial services, how far the VAT system should go in taxing the public sector, border tax adjustment in the absence of border controls and the extent that service can be comprehensively included VAT. Some of the major emerging issues and recommended approaches are summarized as follows.

\section{A. The Rates of VAT To be Imposed}

The key issue here is how to make the rate differentiation capable of accommodating equity considerations. Another cardinal question here is whether maintaining multiple rates and using the enhanced revenue that this generates to finance well-targeted pro-poor spending is a better option. Experience suggests that multiple rates increase compliance and administrative costs, apart from facilitating evasion. Hence, generally, single rate VAT is recommended. 


\section{B. The exemptions to be granted}

The increasingly rampant proliferation of exemptions in VATs are often justified by some jurisdictions on the ground that the output (such as financial service) is difficult to tax and/or is a practically convenient substitute for a reduced rate. Practicable alternatives to exemption exist, namely a cash-flow form of VAT and a zero rate for supplies by financial service providers. The best practice however is to allow a short list of exemptions which are limited to basic health, education, and financial services.

\section{The Threshold}

One issue here is deciding on what should be the VAT threshold level. Another is finding out the likely effect of VAT itself and the registration threshold on the behaviour of small firms. According to Lockwood (2015), most countries around the world have thresholds based on the values of goods and services that a business provides. Apart from the most common case of a single threshold, other alternatives in thresholds include different thresholds for different activities and sliding adjustments to the tax liability of entities below the threshold. A high threshold is generally preferable since its use involves economizing on the scarce adminstrative resources.

\section{The Appropriateness of VAT In Small Countries}

The issue of deciding on the appropriateness of VAT in small countries is important to the future spread of the VAT. Since smaller economies tend to rely more on trade, it is reasonable to expect VATs to actually perform well in small countries.

\section{E. International Issues}

With respect to international trade, the question is whether VAT should be levied based on the destination or origin principle. The standard and recommended approach is levying the VAT on domestic consumption through the destination principle. What this implies is that the total tax paid in relation to a commodity is determined by the rate levied in, and revenue accruing to, the jurisdiction of its final sale. In spite of the current trends toward regional integration, the development of the internet has complicated such process.

\section{F. Federalism}

The question here is whether it is better to use VAT as a sub-national tax in federal countries, with lower levels of government having some autonomy in the design of VAT or at the national level.It is recmmended that VAT be implimented at the national level due to the absence of internal borders and the problems with cross-jurisdictional crediting.

Another emerging VAT issue perculiar to Nigeria is the introduction by many State Governments of other consumption taxes on persons and transactions within their jurisdiction. For intance, in 2009, Lagos State, enacted the Hotel Occupancy and Restaurant Consumption Law of Lagos State (Hotel Consumption Law), which imposes consumption tax at $5 \%$ on the value of goods and services consumed in hotels, restaurants and event centres within Lagos State. Kano State equally enacted a similar law (Ango \& Filani, 2019). According to the authors, the validity of such consumption taxes has been contested and has been a subject of litigation in different courts and the resulting judgments have given rise to divergent commentaries.

\section{The computational analysis and development of VAT in Nigeria}

\subsection{VAT Computation and Remittance In Nigeria}

In Nigeria, VAT is now a $7.5 \%$ charge on all the vatable goods and services. Those required by the law to pay VAT are expected to remit the VAT charged to invoices on behalf of the FIRS. However, while doing so, they are expected to deduct certain VAT expense (called input VAT) that they have incurred (ObiChukwu, 2012). 


\subsubsection{New procedure for VAT Rmittance}

A recent public notice issued from the Office of the Executive Chairman of FIRS on 10th March, 2020 introduced Automated Value Added Tax filing and collection system in Nigeria.The new system takes effect from April 1,2020 and thereafter becomes the approved channel for all VAT returns filing and payment processing (see appendix for the details).

\subsection{Procedure for deducting VAT in Nigeria}

A 7.5\% VAT is expected to be reflected on the invoices raised for the sale of goods or services. For example, if one purchases a Laptop from Shoprite for N107,500, that amount will include a VAT of N7500.[N107,500/1.075=N100,000.N107,500 $-N 100,000=N 7,500]$. Since Shoprite is not in the business of manufacturing laptops but is mainly a retail outlet, it must have purchased the laptop at a lower price before adding its mark-up as VAT to arrive at the selling price of N107,500. Assuming that the laptop cost Shoprite N91,375 inclusive of VAT of 7.5\%, Shoprite would have paid a sum of N6,375 as VAT.Based on the information above, one can now calculate how much Shoprite is to remit to the Federal Inland Revenue Servce(FIRS) as follows:- Output VAT of N7,500 less input VAT of N6,375 equals N1125. This is the amount of VAT remittable to the FIRS.

According to Fowler(2016), the following principles must be obeyed while computing VAT in Nigeria:-

(1) The input VAT to be allowed as a deduction from the output tax shall be limited to the tax on the goods purchased or imported directly for resale.It will also be allowed on the goods which form the stockin-trade used for the production of any new product on which output tax is chargeable.

(ii)TheVAT incurred on administrative expenses or overheads does not qualify as allowable input VAT; it is to be expensed in the profit and loss account together with the related expenses.

(iii)The VAT paid on the procurement of capital assets does not qualify as input VAT; instead, it should be capitalized.

(iv)The VAT Act does not provide for input tax claims on supplies of services

(v)The VAT on inputs for the production of exempted goods are to be written off in the income statement.

(vi)The VAT on input for the production of zero-rated products should be retrieved from FIRS through the refund claims application.

(vii)Reimbursable expenses (where applicable) that are not part of the fees should be clearly and separately disclosed on the invoice. VAT is not applicable to them.

(viii)The VAT element of a transaction is to be openly stated on the face of the related invoice.

\subsection{Contributions of Value Added Tax to the Nigerian economy}

The adoption of the VAT system helped Nigeria immensely in diversifying her revenue base and enhancing her internally generated revenue. For instance, her VAT revenue was 7.26 billion in 1994, \#20.76 billion in 1995, $\$ 31$ billion in 1996 and $\$ 34$ billion in 1997. Also, a VAT revenue of 1.97 trillion was paid into Nigeria's Federation account after the first half of the year 2015.In the 2018 fiscal year, VAT receipts amounted to 1.1 trillion. Based on this astronomical increase in VAT collection, the Nigerian Government projected an increase in VAT revenue collection efficiency from the average of $21 \%$ in 2019 to at least $35 \%$ by 2022 (Ezomike \& Ango,2019). The details of VAT collected by Federal Inland Revenue Service from the year of its introduction to 2004 are as follows: 
Table 1. VAT collected by Federal Inland Revenue Service

\begin{tabular}{|c|c|}
\hline Year & Amount (N billions) \\
\hline 1994 & 8.20 \\
\hline 1995 & 20.232005192 .70 \\
\hline 1996 & 32.472006232 .70 \\
\hline 1997 & 14.742007312 .60 \\
\hline 1998 & 38.282008401 .70 \\
\hline 1999 & 47.682009481 .40 \\
\hline 2000 & 60.682010564 .89 \\
\hline 2001 & 91.752011659 .15 \\
\hline 2002 & 108.602012710 .50 \\
\hline 2003 & 131.422013795 .60 \\
\hline 2004 & 163.302014616 .90 \\
\hline
\end{tabular}

Source: Nwachukwu (2013) and Obadan (2015)

\section{VAT Administration in Nigeria}

In Nigeria, VAT replaced the sales tax regime which came into existence through the promulgation of Decree No.7 of 1986. It is claimed to have found its way into the economic agenda of Nigeria in 1986. It was later jettisoned by Dr. Chukwu Okongwu, a former Minister of Finance, in 1991.However, the quest to introduce VAT in Nigeria was re-ignited by the Dr. Sylvester Ugoh led study group on indirect taxation.This group swung into action in November, 1991 (Omesi \& Nzo, 2015). Based on the study group's report, a committee was set up under the chairmanship of Mr. Emmanuel ljewere to carry out a more extensive research on the subject - matter and make recommendations. Based on the recommendations of this second group, VAT was finally adopted in Nigeria in 1993 and started to be implimented with effect from January, 1994 through the instrumentality of the Value Added Tax Act No. 102 of 1993 (Ugwa \& Embuka, 2012). From then, VAT started to be imposed on selected goods and services at a uniform rate of $5 \%$. In 2007, few attempts were made to increase the rate to about $10 \%$ through the enactment of Value Added Tax Act No. 2 of 2007 but failed as the Nigerian public resented such increase. However, the VAT rate was increased to 7.5\% through the Finance Act 2019. It took effect from January, 2020. All the proceeds of VAT flow into the VAT pool account and are distributable on monthly basis to the Federal, States (including the Federal Capital Territory) and Local Governments in the proportion of $15 \%, 50 \%$ and $35 \%$ respectively (Fowler, 2016; Sani, 2011). The sharing of the VAT proceeds is done in such a maner that also reflects the revenue derivation principle of Nigeria.The VAT Act No. 102 of 1993 provides that certain goods and services are exempted from VAT, namely medical and pharmaceutical products meant for kids, basic food items, commercial vehicles and their parts, books and other educational materials, fertilizer, farming machines, agricultural products, magazines and newspapers, etc. (Owolabi \& Okwu, 2011).

Value Added Tax is administered in Nigeria by the FIRS through its VAT directorate in Abuja and in line with Section 7 of the VAT Act. Section 8 subsection 1 of the VATAct compells businesses to register for VAT within the first six months of their commencement. The enterprise wanting to do business with an agency of any of the tiers of Nigerian government are required to show evidence of VAT registeration and past VAT remittances. A registered person is required to make VAT returns monthly and either pay to or recieve from the FIRS the difference between the input VATs and the output VAT. Section 32 of the VAT Act, as amended, authorizes the FIRS to seal up the premises from where the economic activity in question is being carried on within the territory of Nigeria for VAT defaulters.

\subsection{Recent Amendments to the Value Added Tax Law as contained in the Finance Act 2019}

The Finance Act 2019 amends sections 2, 4, 10, 15 and 46 as well as the First Scedule of the VAT Act.The following are the major amendments to the Value Added Tax law as reflected in the Nigerian Finance Act 2019.

(i)The VAT rate is raised from $5 \%$ to $7.5 \%$. 
(ii) A threshold of 25 million of turnover in a calendar year is placed as the threshold for VAT registration. Accordingly, any one who does not fall within the threshold above would be exempted from registering, remitting, issuing tax invoice and collecting VAT.

(iii) The meaning of supply and the definition of goods and services are now to cover intangible items.

(iv) The reverse charge rule is introduced in the VAT law. This rule requires the recipients of goods and services supplied in Nigeria to self-account for VAT on goods purchased from non-residents.

(v) The definition of exported service has been modified to include the services provided within and outside Nigeria by a person in Nigeria to a non-resident person or company.

(vi) The VAT charge on the sale or transfer of business assets and management of related parties stands removed.

(vii) The definition of taxable goods now includes incorporeal properties such as interests in oil concessions. This could be interpreted to mean that shares would now become liable to VAT.

(viii) The remittance of VAT is now to be on cash basis; that is, the difference between the output VAT collected and input VAT paid in the preceding month.

(ix) The requirement for foreign entities carrying on business in Nigeria to register for VAT in Nigeria and include VAT charges in their invoices has been removed.

(x) Specific description of what constitutes basic food items, within the meaning of the VAT Act, for VAT exemption purposes has been made. The recent amendments exempt the locally manufactured sanitary pads, tampons,towels as well as nursery, secondary and tertiary education tuition fees from VAT.

\subsection{Challenges in the Nigerian Value Added Tax System}

The following are some of the challenges confronting the Nigerian VAT system:

(i)The current VAT system disallows input VAT claims on capital goods and services. This has the effect that the VAT paid by manufacturers and service providers would be incurred as a business cost. This situation puts the Nigerian manufacturing and related sectors at a disadvantage when compared with their counterparts elswhere.

(ii)The issue of tax evasion raises a major issue as a nunmber of tax payers are not captured within the tax net.

(iii)Lack of sufficient database and information. This constitutes a major challange to proper taxation of the informal sector.

(iv)There is a lot of inefficiencies and leakages in the system which reduce the amount of revenue that otherwise could be collected.

(v)The deduction of VAT at source by the Nigerian government and companies in the oil and gas sector from the payments made to their suppliers. This leaves such suppliers with claimable input VAT without adequate output VAT- thereby resulting in a perpetual refund position.

(vi)VAT proceeds are considered in some quarters as being distributed inequitably among the states and collected centrally contrary to the provisions of the 1999 constitution of the Federal Republic of Nigeria. For instance, it is argued that since the transactions that give rise to the bulk of VAT collection take place in Lagos State, the state should be receiving a lion share of the proceeds. This contrasts with what happens in reality as, according to the editorial of the PunchNewspapers (21 August, 2017). "some areas labour to produce the wealth, while others position themselves to grab the lion's share of what is available for sharing".

\subsection{Debate $b$ on the recent increase of VAT rate in Nigeria}

In a strategic revenue growth initiative championed by the Federal Ministry of Finance, a VAT rate increase was packaged. As a result,one major highlight of the Finance Act 2019 was the $50 \%$ increase in the VAT by the Nigerian government. This was allegedly carried out for the purpose of generating more internal revenue which would primarily enable government to pay the new minimum wage and reduce Nigeria's fiscal deficits. Ever before the increase in the VAT rate became operational, a lot of fierce debates took place among the various interest groups in Nigeria. The government and some analysts, especially those close to the corridors of power, considered the VAT increase as a progressive move aimed at increasing 
revenue for government. They argued also that since those with higher incomes presumably spend more of their disposable incomes, they would pay more VAT. For them, this might lead to increased revenue which government could use to carry out its developmental plan. In the contrary, the opposition and labour disagreed vehemently with the following defence:

(i)Incease in VAT rate is likely to lead to some increase in corruption and mismanagement especially at the State level since most of the revenue generated therefrom might neither be earmarked for capital projects nor for education.

(ii) Since VAT is basically levied on consumption, the resultant diminished scale of consumption in the Nigerian economy may have some impact on the collection performance of VAT.

(iii) From the point of view of economics, an increase in the VAT rate is likely to affect the poor citizens disproportionately.

(iv) Any upward shift in indirect taxes will affect the prices of goods and services and consequently lead to a rise in inflation rate.

(v) Increasing VAT rate now is ill-timed and not consistent with the current economic reality in Nigeria. The reason is that such a move is likely to push up the inflation rate, lead to a hike in interest rate, create more unemployment and generally make people poorer than they may have been. It is reasoned that attempting to broaden the VAT base while also increasing the VAT rate at the same time is a faulty tax strategy.

(vi) Increasing the tax rate is likely to compell companies to increase the prices of their products sgnificantly. They would ultimately shift the incidence of the tax increment on the consumers. This looks like designing a tax policy aimed at 'robbing Peter to pay Paul'. The new rate may have a detrimental effect on Nigerian economy because its reductive effects on consumers' disposable income can lead to a cotraction in the general economic activities.

(vii) Nigeria is still practising a modified VAT system where the taxpayers can claim only a limited portion of input VAT against output VAT charged (Deloitte, 2019). That being the case, the increment of the VAT rate may end up having higher negative impact, in the absence of a corresponding adjustment to the VAT.

(viii) The increase in VAT rate may lead to interest rate hike, create more unemployment, and generally increase the burden on the poor and Small and Medium Enterprises (SMEs), contrary to the 2017 National Tax Policy.

(x) VAT increase will possibly discourage foreign investment in the Nigerian industrial climate as well as the SMEs. Also, the companies that are unable to increase the prices of their products commensurately may resort to laying off their workers so as to manage cost.

(xi) An increase in VAT rate will be counter-intuitive to the goal of poverty and inequality disparity reduction, given the existng high economic disparity in Nigeria. At the moment, there is already a high cost associated with the poor masses having access to economic opportunities in the country (CSL Stockbrokers, 2019).

(xii) There is no guarantee that the benefits of increasing VAT will be worth the pain of such increment on Nigerians. An implication of the Laffer curve [a principle that defines the connection between the rates of taxation and the resulting levels of government revenue] is that reducing or increasing the tax rates beyond a certain point will be counter-productive for raising higher tax revenue (Adesoji, 2019).

(xiii) The provision in the VAT portion of the Finance Act 2019 that expands the definition of taxable goods to include incorporeal properties, such as interests in oil concession, iss likely to discourage divestment activities which may hamper governments local contents efforts. The sale of interests in oil concessions now attracts VAT of $7.5 \%$. This amendment to the Act is capable of increasing the transaction costs for disvestment transactions. The effect of this will largely be felt by the local firms that may be making efforts to raise finance to acquire new assets.

(xiii) As of now, oil servicing companies are unable to offset the input VAT they incurred against the output VAT chrged as a rersult of the the requirement of the VAT Act that the companies operating in the oil and gas sector should deduct VAT at source on vendor invoice. This arrangement compells such companies to remain in a perpetual VAT refund position. 


\section{Conclusions and recommendations}

This paper examined the Value Added Tax system, identified its global emerging issues and their related consequences. Further, it highlighted the development of VAT and its computational analysis, particularly as it relates to Nigeria. Currently, VAT has gained much pupularity universally, inspite of the several emerging issues militating agaist its efficient administration. Empirical studies have revealed that, in the near future, VAT systems might be replaced with retail sales taxes and be managed and administered almost entirely through the use of technology. In Nigeria, the VAT law, which has a lot of challenges, has been subjected to several amendments. The latest of the amendments which led to increasing the VAT rate fom $5 \%$ to $7.5 \%$ has generated fierce debates among several interest groups. The contention in some quarters is that, even if VAT increment ends up enhancing the total revenue generation yield of Nigeria, it may affect the per capita income of Nigerians negatively and widen the income inequality already existing in the Nigerian economy unless the necessary palliatve measures are quickly takens. Based on this observation, the Nigerian government is advised to have a second look at the necessity and timeliness of the current VAT amendment and consider adopting the necessary palliative measures which include but are not limited to

(i)modifying the recent VAT system in such a manner that will permit taxpayers to claim all input VAT incurred against output VAT charged;

(ii)intensifying efforts in devising an effective means of taxing the informal sector and, by so doing, bringing more people into the tax net;

(iii)making adequate arrangement to retrieve VAT proceeds instantly from companies and the government agents that are involved in VAT collection;

(iv)modifying the existing tax policy in favour of scaling back or eliminating some of the tax breaks/reliefs that currently exist in the tax laws;

(v) broadening the existing taxes;

(vi)strengthening the tax enforcement machinery and improving upon the implementation procedures as well as adminstrative efficiency

(vii) exempting all essential consumer items such as foods, education, primary health care, etc. from VAT;

(vii)creating a reasonable VATregisteration threshold to remove VAT compliance burden for small businesses and insisting that every business whose turnover is above the threshold is VAT- compliant.

(vii) limiting arbitrary waivers so as to expand the VAT base;

(viii)adopting such fiscal policies as will enhance investment in agriculture, industries and technology and thereby stimulate overall productivity growth;

(ix)making the VAT refund system to function in such a manner that the businesses in a refund position are paid promptly.[Ruanda pays VAT refund within 30 days].

(x)ensuring that all the MDAs fully comply with the VAT Act by remitting the VAT they collect from contractors accordingly;

(xi)insisting on transparent reporting and efficient utilization of the tax revenue for public services and infrastructure, and

(xii)making VATs on goods and services to be broad-based and integrating a long-term perspective so as to make them effective and

(xiii)disallowing the introduction of other consumption taxes by other tiers of government in Nigeria.

\section{References}

1. Abdullah, A., Doucouliagos, H., \& Manning, E. (2015). Does education reduce income inequality? A meta-regression analysis. Journal of Economic Surveys, 29, 301-316. doi:10.1111/joes.12056.

2. Abiola, J., \& Asiweh (2012). Impact of tax administration on government revenue in a developing economy: A case study of Nigeria. International Journal of Business and social science, 3 (8), 99-112.

3. Adams, S. (1921). 'Fundamental Problems of Federal Income Taxation, QuarterlyJournal of Economics 35 (4) (1921), 528, 553.

4. Adereti, A. \& Sanni, L. (2011) European. Journal of humanities and social sciences.10 (1) 
5. Adesina, M., \& Famous, B. (2013). Public Perception and Attitude towards Value Added Tax (VAT) in Nigeria. Research Article The Experiment, 33(1), 2071-208.

6. Adesoji, S. A. (2019). Nigeria's VAT increase: Penny-wise,Pound foolish.

7. Afolayan, G., \& Okoli, O. (2013). The impact of value added tax on Nigeria Economic Growth. European Journal of Business and Management, 7 (9).

8. Ahlerup, P., Baskaran, T., \& Bigsten, A. (2015). Tax innovations and public revenues in Sub-Saharan Africa. The Journal of Development Studies, 51(6), 689-706. doi:10.1080/00220388.2014.997223

9. Ajakaiye, D. O. (1999). Macroeconomic effects of VAT in Nigeria: Empirical analysis. International research journal of finance and economics issue 95, 51-61.

10. Ajala, O., and Ayorinde (2010) http;//www.pwc.com/payingtaxeshttp://www.pwc.com/paying twww.pwc.com/payingtaxes

11. Alavuotunki, K., Haapanen, M., \& Pirttila, J.(2019). The effects of the Value Added Tax on revenue and inequality. The Journal of bf Development Studies, 55(4); https//:doi.org/10.1080/00220388. 2017.1400015.

12. Alavuotunki, K., Haapanen, M., \& Pirtilla, J. (2018). The effects of the Value-Added Tax on revenue and Inequality; The Journal of Development Studies, 55(4); 490-508. https://doi.org/10.1080/ 00220388.2017.1400015

13. Alireza, H., Fariba, P., \& Akbarian, B. (2012). Impact of fiscal policy on economic growth in Iran with emphasis on the role of Value Added Tax (VAT) Journal Advances in Environmental Biology, 6(2): 916-919, 2012

14. Ango, M., \& Filani, Y. (2019). Validity of consumption tax vis-ávis VAT in Nigeria .Andersen Tax LP

15. Aniechebe, E. (2013). Tax composition and economic growth: An empirical investigation for Greece using casualty analysis. Journal of Social Science, 1(2), 99-104

16. Anyafo, A. M. O. (1996) Public finance in developing economy: the Nigerian case. Department of Banking and Finance University of Nigeria Enugu Campus Enugu.

17. Arisoy, I., \& Unlukaplan, I. (2010). Tax composition and growth in Turkey: An empirical analysis. International Journal of Finance and Economics issue 59, 51-61.

18. Ariyo, A. (1997). Productivity of the Nigerian Tax system: 1970-1990. African. Economic Research constium (AERC) Research paper 67, Nairobi Kenya. Available from: http://www.aercafrica.org/documents/ RP67.PDF. Accessed 28/06/10.

19. Awe, E. (2018). Impact of Value Added Tax on economic growth in nigeria.Management science conference Abuja, Nigeria. October

20. Bakare, A. S. (2013). Value Added Tax and Output Growth in Nigeria: Proceedings of 8th Annual London Business Research Conference Imperial College, London, UK.

21. Bhetia, H. L. (2009). Public finance. New Delhi: Vikas publishing House PVT Ltd. Accessed 28/06/10 from en.wikipedia.org/wiki/tax reform.

22. Bird, R., \& Zolt, E. (2005). Redistribution via taxation: The limited role of the personal income tax in developing countries (School of Law, Law \& Economics Research Paper Series No. 05-22). Los Angeles: University of California.

23. Boadway, R., \& Sato, M. (2009). Optimal tax design and enforcement with an informal sector. American Economic Journal: Economic Policy, 1(1), 1-27. doi:10.1257/pol.1.1.

24. Carter, A. (2013) ed.International Tax Dialogue: Key issues and debates in VAT, SME taxation and the tax treatment of the financial sector (C) Istockphoto.com/WoodenheadWorld

25. Cnossen, S. (198). Global Trends and Issues in Value Added Taxation International Tax and Public Finance 5(3):399-42 DOI: 10.1023/A:1008694529567.

26. CSL Stockbrokers. (2019). Nigeria: Burden of VAT increase on Nigerians. This Day (Lagos).

27. Deloitte. (2019). Nigerian government pro[poses $50^{\wedge}$ increase in VAT rate.

28. Dubay, C. (2010).The Value-Added Tax Is Wrong for the United States, , Tax and Economic Policy .Heritage Foundation

29. Ebiringa, \& Emeh. (2012). Analysis of Tax Formation and Impact on Economic Growth in Nigeria. International Journal of Accounting and Financial Reporting.

30. Emran, M. S., \& Hou, Z. (2013). Access to markets and rural poverty: Evidence from household consumption in China. Review of Economics and Statistics, 95, 682-697. doi:10.1162/REST_a_00354

31. Ezejulue. (2011) Premier on International accounting. Clear print publishing

32. Ezomike, C., \& Ango, M. (2019). Nigeria: How important is the Value Addad Tax to the Nigerian economy? Anderson Tax LP.

33. Fowler, B. (2016). Synopsis of Value Added Tax Administration in Nigeria. 
34. Gemmell, N., Kneller, R., \& Sanz, I. (2014). The growth effects of tax rates in the OECD. Canadian Journal of Economics/Revue Canadienne d'économique, 47, 1217-1255. doi:10.1111/caje.12105

35. Gerard, F., and Naritomi, J. (2020), Value Added Tax in developing countries: Lessons from recent research. London School of Economics and Political Science (LSE)

36. Global Tax Alert. (2019).Nigeria: Update on Finance Bill 2019

37. Ifurueze, M. S. K., \& Ekezie, C. A. (2014) The Nigeria tax system and economic growth: A time series analysis. International Journal of Economics and Empirical Research, 2(4), 163-169 AFRREV, Vol. 9(4), S/NO 39, September, 2015286

38. Itriago, D. (2011). Owning development: Taxation to fight poverty (Oxfam Research Report). Retrieved November 11, 2015, from https://www.oxfam.org/sites/www.oxfam.org/files/rr-owningdevelopment-domestic-resources-tax-260911-en.pdf

39. James, K. (2011). Exploring the origins and global rise of VAT.Tax Analysts Faculty of law, Monash University, Melbourn..

40. Jayachandran, S. (2019) Why a Tax the U.S. Hasn't Embraced Has Found Favor in Much of the World. Economic View, The NewYorkTimes https://www.nytimes.com/2019/05/17/business/value-added-taxenforcement.html

41. Jenkins, S. (2015). World income inequality databases: An assessment of WIID and SWIID. The Journal of Economic Inequality, 13, 629-671. doi:10.1007/s10888-015-9305

42. John, Ebiere \& Emmanuel. (2014). Assessment of the Long-Run Equilibrium Relationship between Tax

43. Kagan, J. (2020). Value Added Tax.Investopedia.

44. Keen, M. (2008). VAT, tariffs, and withholding: Border taxes and informality in developing countries. Journal of Public Economics, 92, 1892-1906. doi:10.1016/j.jpubeco.2008.05.006

45. Keen, M., \& Lockwood, B. (2010). The value added tax: Its causes and consequences. Journal of Development Economics, 92, 138-151. doi:10.1016/j.jdeveco.2009.01.012

46. Loveday, A., \& Nwanyanwu. (2015). Value Added Tax Administration in Nigeria: journal Applied Economics and Finance 2 (4) Published by Red fame Publishing.

47. Lockwood, B. (2015). How does VAT affect the behaviour of small companies? Warwick University

48. Maiye, O., \& Isiadinso, O. (2019). Nigeria: Gaising government revenue through increased VAT rate.Anderson Tax LP.

49. McCarten, W. (2005). The role of organizational design in the revenue strategies of developing countries. Paper presented at global VAT conference, Rome. In the Research Journal of Finance and Accounting countries, 4 (2) 65-77.

50. Miller, A., \& Oats, L. (2009). Principles of international taxation. 2nd edition. West Sussex: Tottel Publishing.

51. Norregaard, J., \& Khan, T. S. (2007).Tax Policy: Recent Trends and ComingChallenges, 39 (IMF, Working Paper 274).

52. Nwachukwu, I. (2013) N4.2 trn VAT revenue boots government 19-year spending. Business Day newspaper, 11 (78), 39.

53. Obadan, M. I. (2015). Case for tax reform and increased VAT in Nigeria, Business Day newspaper, 13 (89), 10.

54. Obiakor, Kwarbai \& Okwu. (2015). Value Added Tax and Consumption Expenditure Behaviour of Households in Nigeria www.irss.academyirmbr.com International Review of Social Sciences 3 (6).

55. Ogungbesan, S. (2015). Value added tax (VAT) in Nigeria. Business day newspaper, 13 (99), 23.

56. Okoyeuzu, C. (2013). Value Added Tax Remittance: observation from developing country. Global Journal of Management and Business Research Finance. Vol 13 (9).

57. Okpe, I. I. (1998). Personal Income Tax in Nigeria. Enugu Ezeugo Printers

58. Okwori, \& Ochinyabo. (2014). A Log Linear Assessment of the effect of value added tax (VAT) on revenue generation in Nigeria. Journal of Emerging Trends in Economics and Management Sciences (JETEMS) 5(7):95-100 Scholarlink Research Institute

59. Olaniyi, T. A., Bello, N., Funmilayo, Y., \& Bolaji, A. (2019). Effect of Value Added Tax and Capital Gains Tax on Economic Growth in Nigeria: Traditional Versus Buoyancy Approach 2019 Entrepreneurial Journal of Management Science (EJMS),5(1) A Publication of the College of Management Sciences,AlHikmahUniversity, Ilorin,Nigeria.ISSN 2276-9471

60. Omesi, I., \& Nzor, N. P. (20150. Tax reforms in Nigeria: Case for Value Added Tax(VAT)>African Research Review;9(4);277-287. 
61. Onodugo \& Anowor. (2013). An evaluation of the contribution of value added tax (VAT) To Resource mobilization in Nigeria. European Journal of Business and Management. 5 (6).

62. Oraka, A. O., Okegbe, T. O., \& Ezejiofor, R. A. (2017).Effect of Value Added Tax on the Nigerian Economy.European Journal of Academic Research 5(2)

63. Oriakhi, D. E. \& Ahuru, R. R. (2014). The impact of Tax reform on Federal revenue generation in Nigeria. Journal of policy and development studies, 9(1), 92-107.

64. Owolabi, S. A., and Okwo, A. T. (2011) Empirical Evaluation of contribution of value added tax to the Development of Lagos State economy, Middle Eastern Finance and Economics, Euro Journals Publishing, 9, assessed from http:www.eurojournals.com/MEFE.htm on July 2, 2011

65. PricewaterhouseCoopers. (2010). Nigeria @ 50: Top 50 Tax Issues www.orandcconsultants.com , downloads > nigeria-top-50-tax-issues

66. PricewaterhouseCoopers LLP. (2010).The impact of VAT compliance on business. www.pwc.com > tax > pdf > impact-of-vat

67. Punch Newspapers. (2017). Redressing injustice in VAT sharing - Punch Newspapers punchng.com > redressing-injustice-in-vat-sharing

68. Remer, C., \& Romer, D. (2000). The macroeconomic effects of tax changes: Estimates based on a new measure of fiscal shocks. http://elsaberkeley.edu/dromer.in The Research Journal of Finance and Accounting, $4(2), 65-77$.

69. Salia, H., \& Atuilik, W. A. (2016). Analysis of value added tax effect on firms' cash flow in various sectors of the emerging economies, Journal of Accounting and Taxation, 8(3),28-39. DOI: 10.5897/JAT2016.0232

70. Sani, A. (2011) Current Law and Practice of Value Added Tax in Nigeria. Retrieved from http://abiolasanni.blogspot.com 26th May

71. Shamsudeen, L. S. (2014). Determinant of tax administration efficiency Retrieved on line /www.

72. Soyode, L., \& Kajola, S. O. (2006). Taxation-principles and practice in Nigeria. Ibadan: Silicon publishing company.

73. Sullivan, C. K. (1965). The Tax on ValueAdded (New York, 1965), 17

74. Thornton, G. (2017). Getting up to speed with VAT/GST in emerging markets. GrantThornton International Ltd.

75. Ugochukwu, M. J., \& Azubike, J. I. B. (2016). Value Addad Tax and economic development in Nigeria.International Journal of Development and Economic Sustainability, 4(3); 1-10.

76. Ugwa, M., \& Embuka, A. (2012). Pay as you consume the value added tax. Gauge: A quarterly publication of the Federal Inland Revenue Service, April June. Ugwu,A.(n.d.). Value added tax in nigeria problems and prospects.

77. Umeora. (2013). The Effects of value added tax on the economic growth of Nigeria. 1(6). Journal of Economics and sustainable Development.

78. Umeora, C. I. (2013), The Effects of Value Added Tax (V.A.T) on the Economic Growth of Nigeria.Journal of Economics and Sustainable Development, 4(6) https://www.iiste.org/Journals/index.php/ JEDS/article/view/5245

79. Wikipedia-The free encopedia.

80. Yakubu, J. P., \& Sansui, N. (2013). Analyzing the impact of value added tax (VAT) on Economic Growth in Nigeria. Mathematic Theory and Modeling 3(14)

81. Wolfers, L., Shen, S., Wang, J., \& and Jiang, A. (2018). VAT: A pathway to 2025.KPMG. 


\author{
Appendix \\ PUBLIC NOTICE
}

Public Notice Mar 10, 202004 .

FEDERAL INLAND REVENUE SERVICE

OFFICE OF THE EXECUTIVE CHAIRMAN

15 SOKODE CRESCENT, ZONE 5, WUSE, P.M.B 33, GARKI, ABUJA, NIGERIA

www.firs.gov.ng

PUBLIC NOTICE

AUTOMATED VALUE ADDED TAX (VAT) FILING \& COLLECTION SYSTEM

AUTOMATED VAT COLLECTION SYSTEM FOR FIRS COVERING; BRANDED SHOPS, SUPER STORES, GENERAL SUPERMARKETS, STANDARD RESTAURANTS AND EATERIES NATIONWIDE.

The Federal Inland Revenue Service wishes to inform the general public of its AUTOMATED VAT COLLECTION SYSTEM for; Branded Shops, Super Stores, General Supermarkets, Standard Restaurants and Eateries Nationwide. This program will enable efficient and seamless collection and remittance of VAT on all eatable transactions in the wholesale I Retail sector as well as enable direct audit/reconciliation of all VAT transactions to ensure compliance with relevant tax laws.

Effective from April 1, 2020, the Automated VAT Platform [VATrac] becomes the approved channel for all VAT returns filing and payment processing, hence your compliance and timely connectivity with the FIRS automated VAT platform is mandatory.

By this notice, all categories of the aforementioned businesses are hereby implored to liaise with the nearest FIRS Tax Office in order to be connected to the FIRS eVAT platform for access and timely compliance.

Furthermore, you are to also ensure that your Transactions/Sales Receipts to customers must henceforth show the following tokens;

1. FIRS Tax Identification Number [TIN] or Joint Tax Board TIN

2. Print Date

3. Goods/Product Description

4. Receipt Number

5. Grand Total billed to the customer

6. Standard 7.5\% VAT amount applicable on the total [as a line item]

As with other FIRS services, please note that the new eVAT Platform is for your 'ease of business' with FIRS and has no disruptive or negative impact on your routine [daily operations] and existing systems, as the platform is built to interoperate with any standard Point of Sales [POS] I Fiscal machine.

Signed:

Muhammad Nami

Executive Chairman

Federal Inland Revenue Service 